\title{
The past, the present and the future of eutardigrade taxonomy
}

\author{
Giovanni PILATO* \\ Dipartimento di Scienze Biologiche, Geologiche e Ambientali, Università di Catania, via A. Longo 19, 95125 Catania, Italy \\ *Corresponding author: pilato@unict.it
}

\begin{abstract}
The Author first recalls the past of eutardigrade taxonomy and indicates the main factors that for a long time restrained its progress. One consequence of a superficial analysis is that very wide individual variability has been erroneously attributed to many species, and this has become the main problem for tardigrade taxonomists. The situation began to change after 1969 because of the first attempts to eliminate the above mentioned problems. Novelties gave impetus to the revision of tardigrade taxonomy, and genuine systematics, finally based on phylogenetics, became popular. Today the morphological characters are considered more in depth and studies utilising DNA sequences are more in fashion; they are surely useful and allow the distinction of morphologically very similar species. However, in the author's opinion, this progress will be possible only if the molecular studies are always associated with careful morphological studies, which, in the meantime, will be more and more detailed also thanks to the use of the Scanning Electron Microscopy (SEM).
\end{abstract}

Key words: tardigrade, taxonomy, evolution.

\section{A HISTORICAL EXCURSION}

\section{Tardigrade taxonomy in the past}

I am sufficiently old, unfortunately, to be able to say something on the past history of tardigrade taxonomy, as well as its present and future. At the beginning of my study of these very interesting animals (1965), I realised from the literature and from the examination of many species from various geographic areas, that, notwithstanding a first phylogenetic approach of Thulin (1928), tardigrade taxonomy was absolutely, and expressly, phenetic; therefore, I tried to understand what rendered it unsatisfactory. Until the beginning of the twentieth century descriptions of tardigrade taxa were usually brief and defective, even those of the most careful authors, such as Murray $(1905,1906,1907,1910,1911)$ and Thulin $(1911$, 1928). Few characters were taken into consideration, whereas others were totally neglected. This fact clearly comes out in Marcus's monographs $(1928,1936)$ and Ramazzotti's monographs of 1962 and of 1972. It can be noted that there was no notice about the buccal armature; about the apophyses for the insertion of the stylet muscles on the buccal tube of the Hypsibiidae, it was reported only that they could be ridge- or hook-shaped, without any other specification; the presence of a cuticular bar on the legs was reported for only two species of Isohypsibius (which in that monograph was still considered a subgenus); the presence of a spiral thickening in the pharyngeal tube in the species of Diphascon (considered as a subgenus of Hypsibius too) was reported for just five of the 32 species known at the time for that taxon; about the claws, only their shape, not the structure, was taken into consideration; the metric characters were sometimes neg- lected or indicated subjectively (small, large, longer, shorter); in other cases they were indicated in absolute value or related to the body length ( $m s$ index), or to the pharyngeal bulb length ( $c p h$ index), thus being nearly unusable as the body and the pharyngeal bulb may vary in length due to a different degree of compression under the microscope cover slip. The drawings of the past descriptions often do not help because they were too generic, or the structures were oriented in an inappropriate position. Unfortunately, the type material of many old species got lost for various causes or never existed because some authors did not mount permanent slides. Besides, many authors, while describing a new species, did not give a thorough description, limiting themselves almost to mentioning only the characters by which that species differed from the already known ones. As a consequence, it might have occurred that an author found a new species, equal to an already known one for the characters indicated in the description, but different for other characters not carefully described or totally neglected; the result might have been that the new species was not recognised and the specimens attributed to the already known species. Combining different species under the same name had quite serious consequences: the differences that someone could note, between what were believed to be populations of the same species, were attributed to intraspecific variability. The same mistake might occur many times, thus producing a vicious circle. All this led scholars to believe that tardigrade species were usually quite variable, thus feeding that vicious circle and creating great confusion. It is also possible that a new species was described because it appeared different from a known species for a character overlooked in the description of the latter. 
That confusion led to another consequence: some animals collected in very distant geographic areas (even different zoogeographic regions) have been attributed to the same species, with very wide geographic distribution attributed to it. This sort of error affected plenty of species. The possibility of passive dispersal let that belief appear justified and this made confusion increase for it induced attribution to intraspecific variability of all the slight differences that could be noted between populations living in even very distant geographic areas.

For many decades, the milestones for the study of tardigrades were the monographs of Marcus $(1928,1936)$ and of Ramazzotti $(1962,1972)$, and then also that of Ramazzotti and Maucci (1983). In their monographs, those authors reported practically all data from the previous literature. In the paper that opened the $3^{\text {rd }}$ International Symposium of 1980 in Johnson City, Tennessee (USA), Ramazzotti and Maucci (1982) wrote about Marcus's monographs: The diagnosis and discussion of each species was extremely accurate, particularly for the oldest and therefore more controversial species; for which type material is usually non-existent or unusable. Marcus's descriptions are adequate today, particularly those descriptions of many common and widespread species. For them, modern taxonomy was based on Marcus's revision more than on the original descriptions, which are sometimes not very accurate, and often scattered in virtually unobtainable publications. [...] At present for all these species, and others as well, a consolidated taxonomy is based on Marcus's interpretations. It is therefore evident that in Ramazzotti's $(1962,1972)$ and Ramazzotti and Maucci's (1983) monographs, the notes on many species came from Marcus's interpretations and I wonder what Marcus's revision exactly means, since this author often did not have the type materials or even the original descriptions of the species in hand. It cannot be excluded that, at least in some cases, his interpretations might have given the idea of some characters which did not correspond to the concrete exactly. Notwithstanding the novelties which had been increasing (Pilato, 1969) about the systematic arrangement of Eutardigrada, in the 1972 edition of his monograph, Ramazzotti followed the classic works of Marcus. I think that in a historical essay it is opportune to record the reasons for Ramazzotti's disagreement with my proposal. He tended to consider the definitions of taxa by the various authors as tenets, thus having difficulty accepting that new information may lead to changes in the definitions. I can state this because Ramazzotti expressed that conviction in his writings, and I find it necessary to give at least one example. In the new arrangement of Eutardigrada proposed by me in 1969, I mentioned the presence of ventral lamina as one of the characters peculiar to the genus Macrobiotus, and its absence as one of the characters peculiar to the genus Hypsibius and others; Ramazzotti, in the monograph of 1972 , on page 676 , wrote: [...] it is not equally certain that Macrobiotus always has buccal tube with ventral lamina and that it is always lacking in Hypsibius [...] as a matter of fact, not all the species have been examined from this point of view, and, besides, we know that species of Hypsibius in which the ventral lamina is present exist: they are those species which Pilato gathers in the genus Doryphoribius. It is therefore evident that Ramazzotti did not conceive that a possible tardigrade with all characters as Macrobiotus but without ventral lamina should simply be ascribed to a different genus, nor did he conceive that a tardigrade with all characters as Hypsibius but with ventral lamina could not be ascribed to Hypsibius but to a different genus. The fact that a species with ventral lamina had been ascribed to the genus Hypsibius was for him a definitive truth, while in my opinion that species had simply to be transferred from Hypsibius to another genus. It must also be stressed that Ramazzotti overlooked the fact, which I realised, that the presence or absence of the ventral lamina always implies other differences; as a matter of fact, if the ventral lamina is lacking, the buccal tube has ventral and dorsal apophyses for the insertion of the stylet muscles so that the symmetry of the buccal-pharyngeal apparatus with respect to the frontal plane changes completely. Besides, the idea that before instituting a genus it is necessary to know first all the species cannot be supported; in that case, no genus could ever be instituted because it is never possible to be sure of knowing all the existing species (including also the extinct ones). In my opinion, and not only mine, it is instead necessary to manage to establish, on the basis of our experience, which characters individualise distinct phyletic lines. Obviously, one must be able to evaluate characters, and must be also ready to change their opinion if novelties prove the past choices wrong.

During the first years of silent study, I became convinced that it was no longer possible to unconditionally accept all the data in Marcus's and Ramazzotti's monographs, and I found essential two things: to always take into consideration primarily the original description of a species, though insufficient and defective, and to build as rich as possible personal collection. I therefore started pestering colleagues asking them for specimens of the species they had found, not only those described by them. So, together with Binda, we have been able to gather a collection that today contains 540 species, nearly 200 of which represented by holotypes, and others, about 180 , by at least a paratype. By working in that manner, I had the opportunity to compare colleagues' opinions with the original descriptions and with the notes in Marcus's and Ramazzotti's monographs. As a result of these actions, I realised that it was necessary re-order the eutardigrade taxonomy and to start its phylogenetic evaluation.

Ramazzotti was too bound to merely descriptive taxonomy, and regarded phylogenetic hypothesis as simple mental exercises which, he wrote on page 677 of his 
monograph of 1972: would complicate, perhaps uselessly, the current simple classification of the Eutardigrada, subdivided into the only two families of Macrobiotidae and Milnesiidae well distinct from each other and which do not set arduous problems of phylogeny. The family Milnesiidae included at that time only one species, while all the other eutardigrades, then almost 300 species, were forced into the sole family Macrobiotidae with only five genera: Macrobiotus, Haplomacrobiotus, Hypsibius, Itaquascon and Hexapodibius. Ramazzotti, even though he did not accept my taxonomic proposals in his monograph of 1972, after few years accepted them almost entirely, and in the Supplement to the monograph of 1972 (Ramazzotti, 1974), wrote on page 72: I propose for the future that new Pilato's arrangement of 1969 should be adopted. The welcome to the novelties by Ramazzotti was almost fully confirmed in the third edition (1983) of the monograph Il Phylum Tardigrada, which was written in collaboration with Maucci (Ramazzotti and Maucci, 1983). In that monograph the genera Minibiotus and Parhexapodibius were not accepted; the species of the former genus were ascribed to Macrobiotus, those of the latter to Hexapodibius; besides, the genus Haplomacrobiotus was still considered as belonging to the family Macrobiotidae and the genus Microhypsibius to the family Calohypsibiidae. In those questionable choices, Maucci's influence was evident, for that author had very different ideas about Haplomacrobiotus and Parhexapodibius from those of mine (Maucci, 1981, 1992), which constrained me to write rather firm specific notes on the Calohypsibiidae (Pilato 1982, 1989, 1992; Pilato and Beasley, 1987). Nevertheless, it is not necessary to linger over these details because all those evaluations of Ramazzotti and Maucci (1983) were not followed by the other tardigradologists. Apart from the above mentioned details, much has changed between the second (Ramazzotti, 1972) and the third edition (Ramazzotti and Maucci, 1983) of the monograph Il phylum Tardigrada, and I would say that 1969 marked the changeover between the past and the present of eutardigrade taxonomy, and I apologise for referring to my paper Evoluzione e nuova sistemazione degli Eutardigradi (Pilato, 1969) as the transition point from a phenetic taxonomy to a currently intended systematic, or a classification which, after the first approach of Thulin (1911, 1928) shaded by Marcus's authority $(1928,1936)$, has started to reflect the phylogeny of the taxon. Evidently, the new taxonomy reached its complete physiognomy also thanks to other authors's publications who approved the novelties and developed them.

\section{Tardigrade taxonomy in the present}

Very synthetically, I find it opportune to recall the main innovations made in eutardigrade taxonomy since 1969. Characters previously neglected began to be taken into con- sideration, e.g. the claw structure (before, only the shape and the symmetry with respect to the medial plane of the leg were considered); the buccal-pharyngeal apparatus structure (its symmetry with respect to the frontal plane is considered, depending on presence or absence of ventral lamina and, if absent, the shape of the apophyses for the stylet muscles insertion); the presence or absence of a thickening between the rigid buccal tube and the flexible pharyngeal tube (of Diphascon species). In subsequent papers (Pilato, 1972, 1973, 1974, 1975) the buccal armature, previously totally neglected, was taken into consideration, and its very low individual variability was shown (variations of which do not deeply change the whole aspect of the armature that is characteristic of the species).

Starting from 1981, a new diagnostic character was proposed, the level of the stylet supports insertion point on the buccal tube expressed as the $p t$ index (i.e. the percent ratio between the length of a structure and the length of a definite portion of the buccal tube). This character has proved to be extremely useful thanks to its very limited individual variability (Pilato, 1981; Pilato et al., 1982; Pilato et al., 2007). The use of the ptd index (i.e. the percent ratio between the length of a structure and the length of a definite portion of the buccal tube measured up to the end of the drop-like structure; Pilato and Binda, 1997/98) and $p b f$ index (i.e. the percent ratio between the length of a structure and the total length of the buccal-pharyngeal tube; Pilato et al., 2002) have been introduced for the subgenus Diphascon. These indices were immediately welcomed by all tardigradologists. It is obviously still necessary to refer the measurements also to the body length, but it is undoubtedly very useful to take also as a datum point the buccal tube which is a rigid structure that can be measured with less error. With respect to the problems posed by allometric growth, it is useful to take into consideration the suggestions of Bartels et al. (2011).

In addition, other characters formerly neglected are the shape of the stylet furcae, which proved to be virtually lacking individual variability, and fine details of the egg shell ornamentation (if present). However, in my opinion the most significant novelty was to challenge the conviction that all the tardigrade species were widely variable. This refutation enabled us to evaluate in a new manner the character's weight and led to a turning point in eutardigrade taxonomy.

I find it opportune to take brief notice of Bertolani's (1971a, 1971b, 1971c, 1972, 1973, 1976, 1977) karyological investigations which recognised strains with different ploidy, within which were those which were morphologically considered as a single species. This gave support to the hypothesis, which seems to find confirmation in recent molecular studies, about the existence of sibling species morphologically very similar, or even not distinguishable. More recently, also investigations on spermatozoa have 
been performed (Guidi and Rebecchi, 1996; Rebecchi and Bertolani, 1999; Rebecchi, 2001; Rebecchi et al., 2011), which too help in resolving the phylogenetic relationships.

The new taxonomy then developed with numerous contributions of other scholars who welcomed the new study criteria and, differently from the past, deepened evaluations with phylogenetic value. The new evaluation of the characters has engendered an explosion in the classification of the Eutardigrada. Today, the Eutardigrada class is divided into the two orders Apochela and Parachela, instituted by Schuster et al. (1980). The order Apochela contains only the family Milnesiidae (with four genera and 21 species), whereas the order Parachela is divided into four superfamilies (Marley et al., 2011), with 11 families (though in my opinion Beornidae and Necopinatidae are questionable) and 56 genera comprising nearly 700 species. A similar revolution has occurred also in the Heterotardigrada, since new characters have been taken into consideration. In this paper I limited myself to deal with eutardigrades, but I cannot overlook the contributions, following 1969, which altogether brought the institution of six new valid families of Heterotardigrada. Just as for the Eutardigrada, so also for the Heterotardigrada, it would be too long to list the more than 30 new genera and the more than 200 new species with their authors, and I apologise to all the colleagues whom I cannot here mention, but I think it is necessary to record at least the contributions of Renaud-Mornant (1974, 1980, 1981, 1982), Kristensen and Hallas (1980), Grimaldi de Zio et al. (1982), Kristensen and RenaudMornant (1983), Kristensen and Higgins (1984, 1989), Grimaldi de Zio and D'Addabbo Gallo (1987); Binda and Kristensen (1986), de Zio Grimaldi et al. (1992, 1995/96), Kristensen (1987), Bello and Grimaldi de Zio (1998).

Descriptions of new species are today no longer defective as they used to be in the past. The use of photomicrographs has spread, together with the use of Scanning Electron Microscopy (SEM) which has proved to be very useful, at the specific diagnosis level, in order to provide evidence of very fine details; the use of SEM started many years ago (Grigarick et al., 1975; Nelson, 1975; Schuster, 1975; Toftner et al., 1975) and it is more and more widespread. Also metric characters are much more in use, and in some cases (particularly with regard to the claws of some genera) it is necessary to measure the length of portions of the structure and to take into consideration the proportions between the different parts (Dastych et al., 2003; Dastych, 2006). Obviously, in order that the data can be compared, it is necessary to measure, photograph or draw, the various structures in standardised positions. About metric characters, I have to linger and make an observation about the use of statistical analyses. I want to point out that statistical analyses are certainly useful when well applied, but may lead to confusion rather than clari- fying problems when not correctly applied, for example when the number of measured specimens is too small or if the researcher is not extremely careful, meticulous and patient in the measurements (extreme attention is necessary in evaluating the orientations of the structures), or when two different species look similar and are confused and considered together, with the frequent result of a false wide variability. Another possible mistake can occur when, not knowing the species, one is not sure about the composition of the population (overall ratio juveniles/adults). So with the incorrect use of statistics on two or more small populations with different compositions, the results may erroneously indicate that the populations belong to different species, or different species with different compositions might appear similar, thus inducing the scholar to attribute them to the same species. A help in species identification is the fact that the individual variability of the dimensions of some structures is very low in specimens of comparable body size (Pilato, 1975, 1981; Pilato et al., 1982, 2007). In this case a correct comparison is possible by comparing one of these characters in specimens having the same, or almost similar, body size. According to Pilato et al. (2007), a difference of 5\% or more in the $p t$ index values relative to the stylet supports insertion point on the buccal tube indicates that the two specimens probably do not belong to the same species, or that the measurements are incorrect or not reliable (i.e. the structures are not in a suitable orientation for measurement). Unfortunately the literature is full of unreliable data such as those with a difference of $10 \%$ within the same species. Besides, if specimens of two close species are erroneously considered as belonging to a single species (and recent molecular analyses are beginning to demonstrate the existence of many groups of sibling species (Faurby et al., 2008; Bertolani et al., 2011), an incorrect statistical analysis of this species would produce a rather high variability (for a tardigrade species) and this result would create confusion which would be difficult to be clarified in the future by other authors.

\section{Tardigrade taxonomy in the future}

Even though observations under phase or differential interference contrast with oil immersion allow the observation of a great deal of detail, probably one of the main goals of future tardigrade taxonomy should be the greater use the SEM. As a matter of fact, SEM allows the observation of details that are magnitudes smaller than those observed with Light Microscopy, thus being particularly useful in recognition of morphologically similar cryptic species, which now are detectable only through molecular means.

I have already shifted to discussing about the future of tardigrade taxonomy and I have to mention immediately the molecular investigations, started in 1996 (Moon 
and Kim, 1996). These investigations have been directed both on phylogeny (Garey et al., 1996, 1999; Giribet et al., 1996; Jørgensen and Kristensen, 2004; Guidetti et al., 2005; Nichols et al., 2006; Guil and Giribet, 2011) and on species identification and distribution (Jørgensen et al., 2007; Schill and Steinbrück, 2007; Faurby et al., 2008; Cesari et al., 2009, 2011; Guil and Giribet, 2009; Bertolani et al., 2011). They will go on, will be more and more thorough and will help us to distinguish between sibling species so similar morphologically that they are now very difficult or even impossible to be distinguished one from another. If so, the scholars will be stimulated to refine the morphological investigations in order to test whether there actually are finer differences between cryptic taxa that were earlier overlooked. Molecular investigations will facilitate also the clarification of the degree of phylogenetic relationships among the taxa.

Together with their benefits, molecular studies also involve some risk which should be borne in mind. I prefer to say something on this topic speaking in general because the problem does not affect only tardigrades. Today it is fashionable to speak about molecular phylogeny, forgetting that the molecular and the morphological phylogeny, separate from each other, do not exist, but, as I already stated (Pilato, 2007), phylogeny is unique, without adjectives. If this is forgotten, I see the primary risk is the fact that some researchers use the molecular approach without having first deepened their knowledge of the morphology of the taxon they intend to study, and I also notice a tendency to generalise (even at the phylum level) molecular data obtained from few species. If there is a disagreement between morphological and molecular studies, traditional taxonomists despair, while many molecular phylogeneticists publish their results with ease, disregarding the contrast with morphology.

Those who want to carry out molecular studies need first to classify the material on which they work, thus having two possibilities: either they are also an expert taxonomist, or they have to entrust the material for classification to their colleagues who specialise in taxonomy. Unfortunately, molecular studies are today much more in fashion than the morphological ones. They are considered more noble and attract financial support much more easily, so we, old masters, have to orient our pupils to that kind of research with the result of a gradual decrease in the number of scholars who are able to classify tardigrades with the use of a microscope. What will happen in some time, if this kind of specialist has disappeared? Will species be described and identified only on the basis of the DNA sequences, ignoring the morphology? I do hope that this will never happen and that it will be remembered that molecular studies always have to be associated with the morphological ones, with the necessary rigour and patience, much patience.

\section{CONCLUSIONS}

Being open-minded to the novelties of the future, without forgetting the past, has always been the best way to make gradual progress in knowledge. Probably, by expressing these ideas I have shown myself to be still too bound to the present, which is the past of the future. It is perhaps an aging scholars' destiny, and I cannot, and, on the basis of my experience, I do not want to, avoid it. Others, when the time is right, will correct my mistakes, but the young, for their part, should not try to completely forget the experience of the old.

\section{ACKNOWLEDGMENTS}

The Author would like to thank the colleagues who kindly sending slides enriched the collection Binda and Pilato and allowed to solve many taxonomic problems: $\mathrm{R}$. Arcidiacono (Catania, Italy), C.W. Argue (Canada), P. Bartels (USA), C.W. Beasley (USA), R. Bertolani (Italy), V. Biserov (Russia), D. Christenberry (USA), M. Claps (Argentina), S.K. Claxton (Australia), H. Dastych (Germany), P. Degma (Slovakia), M.V. Durante (Verona, Italy), P. Fontoura (Portugal), J.J. Friauf (USA), H. Greven (Germany), R. Guidetti (Modena, Italy), D.S. Horning (New Zealand), G. Iharos (Hungary), M. Ito (Japan), K.I. Jönsson (Sweden), A. Jørgensen (Denmark), Ł. Kaczmarek (Poland), R.D. Kathman (Canada), Y. Kiosya (Ukraine), R.M. Kristensen (Denmark), X. Li (China), N. Marley (UK), W. Maucci (Verona, Italy), S.J. McInnes (UK), Ł. Michalczyk (Poland), W.R. Miller (USA), D.R. Nelson (USA), C.A. Nichols (Australia) J. Peluffo (Argentina), L. Rebecchi (Italy), C. Robotti (Italy), G. Rossi (Argentina), R.O. Schuster (USA), Y. Séméria (France), D.V. Tumanov (Russia), and B. Węglarska (Poland). I also thank Dr. Herry A. Meyer, Department of Biology and Health Sciences, McNeese State University, Lake Charles, Louisiana, USA, who kindly improved my English.

\section{REFERENCES}

Bartels PJ, Nelson DR, Exline P, 2011. Allometry and the removal of body size effects in the morphometric analysis of tardigrades. J. Zool. Syst. Evol. Res. 49(Suppl.1):17-25.

Bello G, de Zio Grimaldi S, 1998. Phylogeny of the genera of the Stygarctidae and related families (Tardigrada, Heterotardigrada). Zool. Anz. 237:171-183.

Bertolani R, 1971a. Partenogenesi geografica triploide in un tardigrado (Macrobiotus richtersi). Atti Accad. Naz. Lin. 50:487489.

Bertolani R, 1971b. [Contributo alla cariologia dei tardigradi. Osservazioni su Macrobiotus hufelandi]. [Article in Italian]. Atti Accad. Naz. Lin. 50:7732-775.

Bertolani R, 1971c. [Osservazioni cariologiche su biotipi bisessuati e partenogenetici in Hypsibius oberhaeuseri (Tardigrada)]. [Article in Italian]. Atti Accad. Naz. Lin. 51:411-413.

Bertolani R, 1972. [Osservazioni cariologiche su alcuni Macro- 
biotus (Tardigrada)]. [Article in Italian]. Atti Accad. Naz. Lin. 52:220-224.

Bertolani R, 1973. [Primo caso di una popolazione tetraploide nei Tardigradi]. [Article in Italian]. Atti Accad. Naz. Lin. 55:571574.

Bertolani R, 1976. [Osservazioni cariologiche su Isohypsibius augusti (Murray, 1907) e I. megalonyx Thulin, 1928 (Tardigrada) e ridescrizione delle due specie]. [Article in Italian]. B. Zool. 43:221-234.

Bertolani R, 1977. [Analisi cariologica e morfologica di alcune popolazioni di Macrobiotus hufelandi (Tardigrada) della Valsesia]. [Article in Italian]. Atti Accad. Naz. Lin. 62:239245.

Bertolani R, Giovannini I, Rebecchi L, Cesari M, 2011. DNA barcoding and integrative taxonomy of Macrobiotus hufelandi C.A.S. Schultze 1834, the first tardigrade species to be described, and some related species. Zootaxa 2997:19-36.

Binda MG, Kristensen RM, 1986. Notes on the genus Oreella (Oreellidae) and the systematic position of Carphania fluviatilis Binda, 1978 (Carphaniidae fam. nov., Heterotardigrada). Animalia 13:9-20.

Cesari M, Bertolani R, Rebecchi L, Guidetti R, 2009. DNA barcoding in Tardigrada: the first case study on Macrobiotus macrocalix Bertolani \& Rebecchi, 1993 (Eutardigrada, Macrobiotidae). Mol. Ecol. Resour. 9:699-706.

Cesari M, Giovannini I, Bertolani R, Rebecchi L, 2011. An example of problems associated with DNA barcoding in tardigrades: a novel method for obtaining voucher specimens. Zootaxa 3104:42-51.

Dastych H, 2006. A new tardigrade species of the genus Ramazzottius, Binda \& Pilato, 1986 (Tardigrada) from the nival zone of the Mont Blanc Massive (The Western Alps), with some morphometric remarks. Mitt. hamb. zool. Mus. Inst. 103:33-45.

Dastych H, Kraus H, Thaler K, 2003. Redescriptions and notes on the biology of the glacier tardigrade Hypsibius klebesbergi Mihelcic, 1959 (Tardigrada), based on material from the Ötztal Alps. Mitt. hamb. zool. Mus. Inst. 100:77-100.

de Zio Grimaldi S, D'Addabbo Gallo M, Morone De Lucia MR, 1992. Neoarctus primigenius n. gen. n. sp., a new Stygarctidae of the Tyrrhenian Sea (Tardigrada, Arthrotardigrada). B. Zool. 59:309-313.

de Zio Grimaldi S, D'Addabbo Gallo M, Morone De Lucia MR, Troccoli A, 1995/96. Hemitanarctus chimaera n. gen. n. sp., new Halechiniscidae from the Ionian Sea (Tardigrada, Heterotardigrada). Zool. Anz. 234:167-174.

Faurby S, Jönsson KI, Rebecchi L, Funch P, 2008. Variation in anhydrobiotic survival of two eutardigrade morphospecies: a story of cryptic species and their dispersal. J. Zool. 275:139-145.

Garey JM, Krotec M, Nelson DR, Brooks J, 1996. Molecular analysis supports a tardigrade-arthropod association. Invertebr. Biol. 115:79-88.

Garey JR, Nelson DR, Mackey LY, Li J, 1999. Tardigrade phylogeny: congruency of morphological and molecular evidence. Zool. Anz. 238:205-210.

Giribet G, Carraza S, Baguna J, Rintort M, Ribera C, 1996. First molecular evidence for the existence of a Tardigrada + Arthropoda clade. Mol. Biol. Evol. 13:76-84.

Grigarick AA, Schuster RO, Toftner EC, 1975. Morphogenesis of two species of Echiniscus. In: R.P. Higgins (ed.), Int. Symp. Tardigrades. Mem. Ist. Ital. Idrobiol. 32:133-151.
Grimaldi de Zio S, D’Addabbo Gallo M, 1987. Archechiniscus minutus n. sp. and its systematic position within Arthrotardigrada (Tardigrada, Heterotardigrada), p. 253-260. In: R. Bertolani (ed.), Biology of tardigrades. Selected symposia and monographs. Mucchi ed.

Grimaldi de Zio S, D’Addabbo Gallo M, Morone De Lucia RM, 1982. [Neostygarctus acanthophorus n. gen., n. sp., nuovo tardigrado marino del Mediterraneo]. [Article in Italian]. Cah. Biol. Mar. 23:319-323.

Guidetti R, Gandolfi A, Rossi V, Bertolani R, 2005. Phylogenetic analysis in Macrobiotidae (Eutardigrada, Parachela): a combined morphological and molecular approach. Zool. Scr. 34:235-244.

Guidi A, Rebecchi L, 1996. Spermatozoon morphology as a character for tardigrade systematics: comparison with sclerified parts of animals and eggs in tardigrades. Zool. J. Linn. Soc.Lond. 116:101-113.

Guil N, Giribet G, 2009. Fine scale population structure in the Echiniscus blumi-canadensis series (Heterotardigrada, Tardigrada) in an Iberian mountain range: when morphology fails to explain genetic structure. Mol. Phylogenet. Evol. 51:606-613.

Guil N, Giribet G, 2011. A comprehensive molecular phylogeny of tardigrades-adding genes and taxa to a poorly resolved phylum-level phylogeny. Cladistics 27:1-29.

Jørgensen A, Kristensen RM, 2004. Molecular phylogeny of Tardigrada: investigation of the monophyly of Heterotardigrada. Mol. Phylogenet. Evol. 32:666-670.

Jørgensen A, Møbjerg N, Kristensen RM, 2007. A molecular study of the tardigrade Echiniscus testudo (Echiniscidae) reveals low DNA sequence diversity over a large geographical area. J. Limnol. 66:77-83.

Kristensen RM, 1987. Generic revision of the Echiniscidae (Heterotardigrada) with a discussion of the origin of the family, $p$. 261-335. In: R. Bertolani (ed.), Biology of tardigrades. Selected symposia and monographs. Mucchi ed.

Kristensen RM, Hallas TE, 1980. The tidal genus Echiniscoides and its variability, with erection of Echiniscoididae fam. $n$. (Tardigrada). Zool. Scr. 9:113-127.

Kristensen RM, Higgins RP, 1984. A new family of Arthrotardigrada (Tardigrada, Heterotardigrada) from the Atlantic coast of Florida, U.S.A. T. Am. Microsc. Soc. 193:295-311.

Kristensen RM, Higgins RP, 1989. Marine Tardigrada from the Southern United States coastal waters. I. Paradoxipus orzeliscoides n. gen., n. sp. (Arthrotardigrada, Halechiniscidae). T. Am. Microsc. Soc. 108:262-282.

Kristensen RM, Renaud-Mornant J, 1983. Existence d'Arthrotardigrades semi-bentiques de genres nouveaux de la sousfamille des Styraconyxinae. Cah. Biol. Mar. 24:337-353.

Marcus E, 1928. [Bartierchen (Tardigrada)], p. 1-230. In: F. Dahl (ed.), [Die Tierwelt Deutschland und der angrenzenden Meeresteile]. [Book in German]. Verlag Gustav Fisher, Jena.

Marcus E, 1936. Tardigrada. Das Tierreich 66:1-340.

Marley NJ, McInnes SJ, Sands CJ, 2011. Phylum Tardigrada: a re-evaluation of the Parachela. Zootaxa 2819:51-64.

Maucci W, 1981. [Hexapodibius castrii, nuova posizione sistematica per Hypsibius (Calohypsibius) castrii Ramazzotti, e considerazioni sul genere Hexapodibius Pilato (Eutardigrada Hypsibiidae)]. [Article in Italian]. Atti Soc. Ital. Sci. Nat. Mus. civ. St. Nat. Milano 122:32-36. 
Maucci W, 1992. [Alcune considerazioni a proposito della posizione sistematica del genere Haplomacrobiotus May, 1948 (Eutardigrada, Macrobiotidae)]. [Article in Italian]. Boll. Mus. civ. St. Nat. Verona 16:389-398.

Moon SY, Kim W, 1996. Phylogenetic position of the Tardigrada based on the $18 \mathrm{~S}$ ribosomal RNA gene sequences. Zool. J. Linn. Soc.-Lond. 116:61-69.

Murray J, 1905. The Tardigrada of the Scottish lochs. T. Roy. Soc. Edin-Earth 27:677-698.

Murray J, 1906. Scottish national antarctic expedition: Tardigrada of the South Orkneys. T. Roy. Soc. Edin-Earth 12:323-334.

Murray J, 1907. Scottish Tardigrada, collected by the Lake Survey. T. Roy. Soc. Edin-Earth 24:641-668.

Murray J, 1910. Tardigrada. Rep. Sci. Invest. Brit. Antarctic Exped. 1907-1909 5:81-185.

Murray J, 1911. Arctiscoida. Proc. R. Ir. Acad. 31:1-16.

Nelson DR, 1975. Ecological distribution of tardigrades on Roan Mountain, Tennessee-North Carolina. Mem. Ist. Ital. Idrobiol. 32:225-276.

Nichols PB, Nelson DR, Garey JR, 2006. A family level analysis of tardigrade phylogeny. Hydrobiologia 558:53-60.

Pilato G, 1969. [Evoluzione e nuova sistemazione degli Eutardigradi]. [Article in Italian]. B. Zool. 36:327-345.

Pilato G, 1972. Structure, intraspecific variability and systematic value of the buccal armature of eutardigrades. J. Zool. Syst. Evol. Res. 10:65-78.

Pilato G, 1973. [L'armatura boccale di alcune specie di Macrobiotus (Tardigrada)]. [Article in Italian]. Boll. Accad. Gioenia Sci. Nat. Catania 12:187-202.

Pilato G, 1974. [Struttura dell'armatura boccale di alcune specie di Isohypsibius (Eutardigrada)]. [Article in Italian]. Animalia 1:43-58.

Pilato G, 1975. On the taxonomic criteria of the Eutardigrada. In: R.P. Higgins (ed.), Int. Symp. Tardigrades. Mem. Ist. Ital. Idrobiol. 32:277-303.

Pilato G, 1981. [Analisi di nuovi caratteri nello studio degli Eutardigradi]. [Article in Italian]. Animalia 8:51-57.

Pilato G, 1982. [Descrizione di Hexapodibius bindae n. sp. e discussione sulla famiglia Calohypsibiidae (Eutardigrada)]. [Article in Italian]. Animalia 9:213-226.

Pilato G, 1989. Phylogenesis and systematic arrangement of the family Calohypsibiidae Pilato, 1969 (Eutardigrada). J. Zool. Syst. Evol. Res. 27:8-13.

Pilato G, 1992. [Nuove considerazioni sulla posizione sistematica del genere Haplomacrobiotus May, 1948 (Eutardigrada)]. [Article in Italian]. Animalia 20:13-21.

Pilato G, 2007. The origin and phylogeny of the Metazoans and the theory of the endoderm as secondary layer. Foxwell \& Davies, London.

Pilato G, Beasley CW, 1987. Haplohexapodibius seductor $\mathrm{n}$. gen. n. sp. (Eutardigrada Calohypsibiidae) with remarks on the systematic position of the new genus. Animalia 14:65-71.

Pilato G, Bertolani R, Binda MG, 1982. [Studio degli Isohypsibius del gruppo elegans (Eutardigrada, Hypsibiidae) con descrizione di due nuove specie]. [Article in Italian]. Animalia 9:185-198.

Pilato G, Binda MG, 1997/98. A comparison of Diphascon (D.) alpinum Murray, 1906, D. (D.) chilenense Plate, 1989 and $D$. (D.) pingue Marcus, 1936 (Tardigrada), and description of a new species. Zool. Anz. 236:181-185.
Pilato G, Binda MG, Claxton S, 2002. Itaquascon unguiculum and Itaquascon cambewarrense: two new species of eutardigrades from Australia. New Zeal. J. Zool. 29:97-93.

Pilato G, Costa G, Conti E, Lisi O, 2007. Morphometric analysis of some metric characters of two Macrobiotus species (Eutardigrada, Macrobiotidae). J. Limnol. 66(Suppl.1):26-32.

Ramazzotti G, 1962. [Il Phylum Tardigrada]. [Article in Italian]. Mem. Ist. Ital. Idrobiol. 14:1-505.

Ramazzotti G, 1972. [Il Phylum Tardigrada]. [Article in Italian]. Mem. Ist. Ital. Idrobiol. 28:1-732.

Ramazzotti G, 1974. [Supplemento a Il Phylum Tardigrada]. [Article in Italian]. Mem. Ist. Ital. Idrobiol. 31:69-179.

Ramazzotti G, Maucci W, 1982. A history of Tardigrade taxonomy, p. 11-27. In: D.R. Nelson (ed.), Proc. Third Int. Symp. Tardigrada. East Tennessee State University Press, Johnson City.

Ramazzotti G, Maucci W, 1983. [Il Phylum Tardigrada. Terza edizione riveduta e aggiornata]. [Article in Italian]. Mem. Ist. Ital. Idrobiol. 41:1-1012.

Rebecchi L, 2001. The spermatozoon in tardigrades. Evolution and relationships with the environment. Zool. Anz. 240:525533.

Rebecchi L, Altiero T, Guidi A, 2011. The ultrastructure of the tardigrade spermatozoon: a comparison between Paramacrobiotus and Macrobiotus species (Eutardigrada). Invertebr. Zool. 1:63-77.

Rebecchi L, Bertolani R, 1999. Spermatozoon morphology of three species of Hypsibiidae (Tardigrada, Eutardigrada), and phylogenetic evaluation. Zool. Anz. 238:319-328.

Renaud-Mornant J, 1974. [Une nouvelle famille de Tardigrades marins abyssaux: les Coronarctidae fam. nov. (Heterotardigrada)]. [Article in French]. Cr. Hebd. Acad. Sci. 278:3087-3090.

Renaud-Mornant J, 1980. [Description de trois espèces nouvelles du genre Tanarctus Renaud-Debyser, 1959, et création de la sous-famille des Tanarctidae, subfam. nov. (Tardigrada, Heterotardigrada)]. [Article in French]. Bull. Mus. natl. Hist. nat. Paris 2:129-141.

Renaud-Mornant J, 1981. [Raiarctus calurus n. g., n. sp., et $R$. aureolatus n. sp., Tardigrades (Arthrotardigrada) marins nouveaux]. [Article in French]. Bull. Mus. natl. Hist. nat. Paris 3:515-522.

Renaud-Mornant J, 1982. [Sous-famille et genre nouveaux de tardigrade marins (Arthrotardigrada)]. [Article in French]. Bull. Mus. natl. Hist. nat. Paris 4:89-94.

Schill RO, Steinbrück G, 2007. Identification of tardigrade species using 18S rDNA restriction site variation. J. Zool. Syst. Evol. Res. 45:184-190.

Schuster RO, Grigarick AA, Toftner EC, 1975. Ultrastructure of tardigrade cuticle. Mem. Ist. Ital. Idrobiol. 32:337-375.

Schuster RO, Nelson DR, Grigarick AA, Christenberry D, 1980. Systematic criteria of the Eutardigrada. T. Am. Microsc. Soc. 99:284-303.

Thulin G, 1911. [Beiträge zur Kennetnis der Tardigradenfauna Schwedens]. [Article in German]. Ark. Zool. 7:1-60.

Thulin G, 1928. [Über die Phylogenie und das System der Tardigraden]. [Article in German]. Hereditas 11:207-266.

Toftner EC, Grigarick AA, Schuster RO, 1975. Analysis of scanning electron microscope images of Macrobiotus eggs. Mem. Ist. Ital. Idrobiol. 32:393-411. 